\title{
Innate Lymphoid Cells in Colorectal Cancers: A Double-Edged Sword
}

\author{
Qiutong Huang ${ }^{1,2}$, Wang Cao ${ }^{1,2}$, Lisa Anna Mielke ${ }^{3}$, Cyril Seillet ${ }^{1,2}$, Gabrielle T. Belz ${ }^{1,2,4 *}$ \\ and Nicolas Jacquelot ${ }^{1,2 *}$
}

${ }^{1}$ Walter and Eliza Hall Institute of Medical Research, Parkville, VIC, Australia, ${ }^{2}$ Department of Medical Biology, University of Melbourne, Parkville, VIC, Australia, ${ }^{3}$ Olivia Newton-John Cancer Research Institute and La Trobe University School of Cancer Medicine, Heidelberg, VIC, Australia, ${ }^{4}$ The University of Queensland Diamantina Institute, The University of Queensland, Brisbane, QLD, Australia

OPEN ACCESS

Edited by:

Hergen Spits,

University of Amsterdam, Netherlands

Reviewed by:

Giuseppe Sciumè,

Sapienza University of Rome, Italy

Ennio Carbone,

University of Catanzaro, Italy

David Robert Withers,

University of Birmingham,

United Kingdom

*Correspondence:

Gabrielle T. Belz

belz@wehi.edu.au

Nicolas Jacquelot

jacquelot.n@wehi.edu.au

Specialty section

This article was submitted to

NK and Innate Lymphoid Cell Biology,

a section of the journal

Frontiers in Immunology

Received: 17 October 2019

Accepted: 17 December 2019

Published: 15 January 2020

Citation:

Huang Q, Cao W, Mielke LA, Seillet C,

Belz GT and Jacquelot N (2020)

Innate Lymphoid Cells in Colorectal Cancers: A Double-Edged Sword.

Front. Immunol. 10:3080

doi: 10.3389/fimmu.2019.03080
The immune system plays a fundamental role at mucosal barriers in maintaining tissue homeostasis. This is particularly true for the gut where cells are flooded with microbial-derived signals and antigens, which constantly challenge the integrity of the intestinal barrier. Multiple immune cell populations equipped with both pro- and anti-inflammatory functions reside in the gut tissue and these cells tightly regulate intestinal health and functions. Dysregulation of this finely tuned system can progressively lead to autoimmune disease and inflammation-driven carcinogenesis. Over the last decade, the contribution of the adaptive immune system in controlling colorectal cancer has been studied in detail, but the role of the innate system, particularly innate lymphoid cells (ILCs), have been largely overlooked. By sensing their microenvironment, ILCs are essential in supporting gut epithelium repair and controling bacterial- and helminth-mediated intestinal infections, highlighting their important role in maintaining tissue integrity. Accumulating evidence also suggests that they may play an important role in carcinogenesis including intestinal cancers. In this review, we will explore the current knowledge about the pro- and anti-tumor functions of ILCs in colorectal cancer.

Keywords: tumor immunology, adaptive immunity, innate immunity, tumor immunosurveillance, immunotherapy

\section{INTRODUCTION}

\section{Colorectal Cancer-Epidemiology, Pathophysiology, and Risk Factors}

Colorectal cancer (CRC) is the third most common cancer worldwide with more than 1.8 million patients diagnosed each year (1). Despite intensified screening programs, most patients are diagnosed at the later stages of disease (2). This results in CRC emerging as the second leading cause of death with more than 900,000 deaths every year (1). CRC is a multifactorial and heterogeneous disease (3) with most cases being sporadic and fewer than $5 \%$ of patients with CRC have a positive familial history with inherited germline mutations that increase the risk of tumor development $(3,4)$.

Tumors are widely distributed from the proximal region of the colon to the rectum and each location is associated with different tumor-intrinsic characteristics (5). Most of these tumors arise from benign lesions called polyps, which progressively acquire genetic and epigenetic modifications to form malignant tumors and metastases $(3,4,6,7)$. These include deletions, amplifications, mutations or methylation of the promoter of certain genes such as APC, SMAD4, TP53, BRAF, MYC, KRAS, PTEN, or MLH1 $(3,4,8)$. The risk of developing CRC increases with age $(4,5)$ 
and is higher in men than in women (9). Other environmental factors such as exposure to smoking, alcoholic beverages, the presence of visceral fat and poor dietary patterns are all features associated with a higher risk of developing $\operatorname{CRC}(3,5)$. In addition, inflammatory bowel disease (IBD) and chronic colitis have also been associated with an increased risk of CRC development $(10,11)$. However, improved anti-inflammatory treatments and increased surveillance have been effective in reducing CRC incidence for these patients (12).

\section{Treatment}

The most effective first line treatment for patients diagnosed with localized CRC is surgery. In certain cases, neoadjuvant chemotherapy allows early reduction of the tumor burden to increase the chances of complete tumor resection (3, 4). For patients with metastatic CRC, there are increased treatment options available which include chemotherapies and targeted therapies.

\section{Chemotherapy}

Tumor recurrence occurs in $15-50 \%$ of patients who have undergone complete resection of loco-regional tumor lesions (4). To reduce this risk, patients often receive adjuvant chemotherapy treatment as a first line approach increasing both patient progression free and overall survival $(13,14)$. More recently, chemotherapy has been combined with targeted therapy to further improve patient overall response rates.

\section{Targeted Therapies}

Multiple treatment approaches have been developed in an endeavor to provide curative outcomes for patients. These include targeting oncogenic drivers (RAS, BRAF), receptors of growth factors (EGFR) or pathways involved in angiogenesis such as VEGFR (15). As an example, Bevacizumab, a human IgG1 antibody directed against VEGF-A, increased patient overall and progression-free survival when combined with chemotherapies $(14,16,17)$.

Recent breakthroughs in tumor immunology have revolved around the clinical efficacy of therapeutic antibodies that are designed to block critical checkpoint molecules expressed at the membrane of circulating and tumor-infiltrating immune cells (18). Programmed death-1 (PD-1) blocking antibodies have been shown to induce remarkably durable clinical responses in many different cancer types, including CRC $(19,20)$. These anti-PD-1 sensitive CRC tumors harbor defective mismatch DNA repair mechanism (called microsatellite instability high or MSI high tumors) and is associated with enhanced mutational load, neoantigen formation, $\mathrm{T}$ cell infiltration of the tumor, and immune checkpoint expression $(4,8,20,21)$. However, only half of these CRC patients experience durable clinical responses (22) and many others develop resistance during treatment. To understand the underlying mechanisms, Grasso and colleagues performed large scale genomic analyses of more than 1,200 CRC tumors (23). This revealed that MSI high tumors have a higher rate of mutated genes in critical immune-modulating pathways such as antigen presentation that then drive resistance to treatment. In addition, upregulation of the WNT pathway in both MSI high and microsatellite stable CRC leads to a "cold" tumor microenvironment that is poorly infiltrated by anti-tumor T cells (23). Combined infusion of anti-CTLA- 4 and anti-PD-1 blocking antibodies increased patient survival in metastatic CRC compared to anti-PD-1 treatment alone. However, it also induced higher levels of toxicity (24).

Currently, the use of immunotherapy and its integration into strategies for CRC care are growing (25). However, the quality of the immune response has not yet been fully factored into treatment decisions despite significantly influencing CRC patient outcomes. A better understanding of the tumor immune infiltrate would greatly inform treatment decisions and allow more strategic design of future combination therapies.

\section{THE TUMOR IMMUNE CONTEXTURE IN COLORECTAL CANCER-THE SUCCESS OF THE ADAPTIVE IMMUNE SYSTEM}

Most colorectal tumors develop from glandular epithelial cells of the colon or rectum (26) and evolve through close interaction with their microenvironment and diverse immune cell types. A critical balance between pro- and anti-tumor immune responses determines either the eradication of nascent lesions or the development and progression of transformed cells that form malignant tumors (27). It has been demonstrated that in patients where initial failure to eradicate emerging tumors occurs, immune cells still play a critical role in dictating the patient response to treatment and outcome (2832). To account for the quality of the immune infiltrate, a scoring system called Immunoscore ${ }^{\mathrm{TM}}$ (33) has been developed by tracking adaptive immune cells such as $\mathrm{CD} 3^{+} \mathrm{CD} 8^{+}$ and memory $\left(\mathrm{CD} 45 \mathrm{RO}^{+}\right) \mathrm{T}$ cells (Table 1$)$. This allows the immune infiltrate and its location within the tumor sample to be integrated to stratify patients and accurately predict dissemination to distant metastasis (34), disease-free and overall survival $(30,31,35)$ (Tables 1, 2). However, the impact of innate cells has not been considered. In this review, we will summarize the latest evidence implicating a role for innate lymphoid cells in CRC development and their impact on disease outcome.

TABLE 1 | Parameters examined in Immunoscore ${ }^{\mathrm{TM}}$.

\begin{tabular}{ll}
\hline Cell type & Cytotoxic lymphocytes $\left(\mathrm{CD}^{+} \mathrm{CD}^{+}\right)$ \\
& Memory T cells $\left(\mathrm{CD} 45 \mathrm{RO}^{+}\right)$
\end{tabular}

Memory $\mathrm{T}$ cells $\left(\mathrm{CD} 45 \mathrm{RO}^{+}\right)$

\begin{tabular}{ll}
\hline Location & $\begin{array}{l}\text { Tumor center } \\
\text { Invasive margin }\end{array}$ \\
\hline Density & $\begin{array}{l}\text { 0-low density of both cell populations in both regions } \\
4-\text { high density of both cell populations in both regions }\end{array}$
\end{tabular}

Prognosis-Cox Disease free survival

analysis Overall survival

Disease specific survival 
TABLE 2 | Immunoscore ${ }^{\text {TM }}$ and its association with the risk of relapse.

1 -one cell population in one region

2 -one or both cell population(s) in one or both region(s)

3 -one or both cell population(s) in one or both region(s)

4 -high density of both cell populations in both regions

Low

\section{ROLE OF THE INNATE LYMPHOID CELLS IN COLORECTAL CANCER}

Innate lymphoid cells (ILCs) are the innate counterpart of the $\mathrm{T}$ lymphocytes, mirroring key aspects of their phenotype and function. ILCs are divided into five subsets, classified based on their development, transcription factor expression, cytokine production and functions. These are NK cells, ILC1, ILC2, ILC3, and Lymphoid Tissue inducers (LTi) (36). They are enriched in mucosal tissues, including the intestinal tract (37) and respond to signals derived from their micro-environment such as cytokines, alarmins, and other inflammatory and non-inflammatory stimuli $(38,39)$ to drive appropriate immune responses and maintain tissue homeostasis. In addition, ILCs express particular receptors and ligands at their surface regulating further their function $(40,41)$. NK cells and ILC1 are mainly involved in the early protection against viruses (42), bacteria $(43,44)$, and cancer (45) through the secretion of interferon (IFN)- $\gamma$ and granulocyte-macrophage colony-stimulating factor (46). ILC2 are essential in host protection against helminth and parasites throughout interleukin (IL)-4, IL-5, and IL-13 production (47). ILC3 express mainly IL-17 and IL-22, both cytokines critical to mucosal immune responses and epithelium regeneration (48). Finally, LTi are critical for lymphoid organogenesis (49). Beyond this, significant plasticity occurs between ILC subsets depending on environmental stimuli they receive, thus directly impacting on their effector functions and immune responses (50-55). While ILCs are essential to lymphoid organogenesis and tissue homeostasis, they also participate to the development of autoimmune diseases $(56,57)$ or inflammationdriven carcinogenesis (58) (Figure 1).

\section{Type 1 Innate Lymphoid Cells}

High-dimensional cytometric analyses have revealed that human colorectal tumors are highly infiltrated by NK cells and intraepithelial-like $\operatorname{ILC1}(59,60)$. They secrete cytotoxic molecules such as granzymes and perforin $(59,60)$ and cytokines such as IFN- $\gamma$ following stimulation (59), making them key potential players in cytotoxic anti-tumor responses (Figure 1A). In contrast, a separate study found impaired NK cell infiltration despite elevated levels of chemokines found in CRC tumors (61) (Table 3).

Studies tracking intraepithelial ILC1s have shown that they accumulate in the intestine of patients with Crohn's Disease and in CRC $(51,59,62)$. These intraepithelial ILC1s can be activated by chemokines and cytokines such as IL-18 produced by intestinal epithelial cells (63) or IL-12 from dendritic cells and monocytes (62). This induces IFN- $\gamma$ production in ILC1 which, in contrast to previously mentioned studies $(59,60)$, drives the pathogenesis of anti-CD40-induced colitis in Rag1 ${ }^{-/-}$ mice (62) (Table 3 and Figure 1A). Given these divergent outcomes, further studies are required to analyze the exact role of intraepithelial ILC1, their receptor expression and cytokine production using genetically-modified conditionallydeficient mice and human samples. How intraepithelial ILC1 influence patient outcomes and responses to therapy, is, to date, poorly understood.

NK cells are known to mediate anti-tumourigenic activity (45). In CRC, NK cells effectively eliminate CRC stem cells and cancer-initiating cells, which express lower levels of class I major histocompatibility complex (MHC) but high levels of ligands that bind the natural cytotoxicity activating receptors (NCR) NKp30 and NKp44. Consequently, these cells are "marked" for NK cell mediated lysis (64) providing a mechanism to potentially prevent tumor cell re-emergence or CRC metastasis. However, tumor cells can circumvent this process by differentiating and upregulating MHC class I expression to suppress NK cell activation or by reducing their expression of NCR ligands to escape NK cell-targeted killing (64). Thus, circulating NK cells in CRC patients are often phenotypically altered reflecting these induced changes. These patients exhibit reduced NKp44 expression on their CD56 ${ }^{\mathrm{dim}}$ cells (65), a key subset that normally exhibit potent effector function. In addition, high NKp30 expression on circulating CD56 ${ }^{\text {bright }}$ cells has been associated with a shortened disease-free survival period in CRC patients (65). Other receptors and ligands expressed on NK cells of CRC patients such as activating and inhibitory KIRs (66) or TIGIT (67) have also been suggested to play distinct roles in the development, progression, and metastasis of CRC tumors (Table 3 and Figure 1A). In mice, neutralizing TIGIT markedly prolongs the survival of tumor bearing animals. However, when NK cells are depleted, this effect was completely abrogated highlighting the critical role of NK cells in this context. In addition, tumor infiltrating NK cells can transdifferentiate into ILC1-like cells in the presence of transforming growth factor- $\beta$ (TGF- $\beta$ ) which is particularly abundant in the tumor microenvironment and associated with tumor progression (54). Does TGF- $\beta$ accumulate in CRC tumors? If so, similar NK cell-ILC1 transdifferentiation could occur in CRC tumors and this would potentially with worsen prognosis. Collectively, it is clear that NK cells are involved in the control of CRC progression and metastasis but are also susceptible to tumor-directed dysregulation (41). To circumvent such events, current NK cell-based therapies are designed to boost NK cell functions in an effort to strategically further improve patient outcomes (68-71).

\section{Type 2 Innate Lymphoid Cells}

The role of ILC2 has been examined in a number of different cancers including lung and gastric cancer $(72,73)$. Nevertheless, their role in colorectal cancer is, to date, only poorly understood. In fact, they are found to a relative lower frequency compared to other ILC subsets that reside in the intestine. Nevertheless, ILC2 frequency is increased in mucosal samples from IBD patients 


\section{Anti-tumour response}

\section{Pro-tumour response}

A

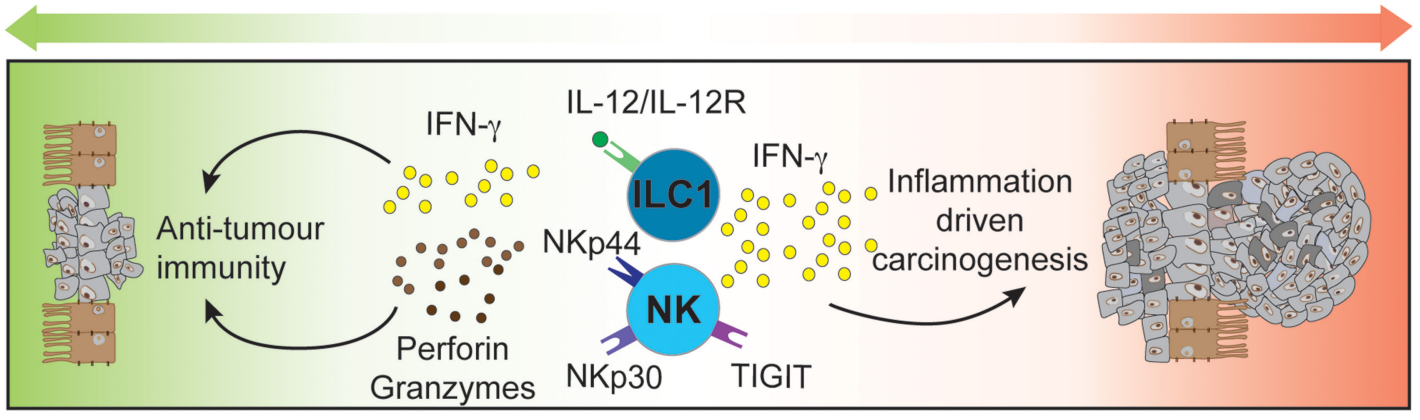

B

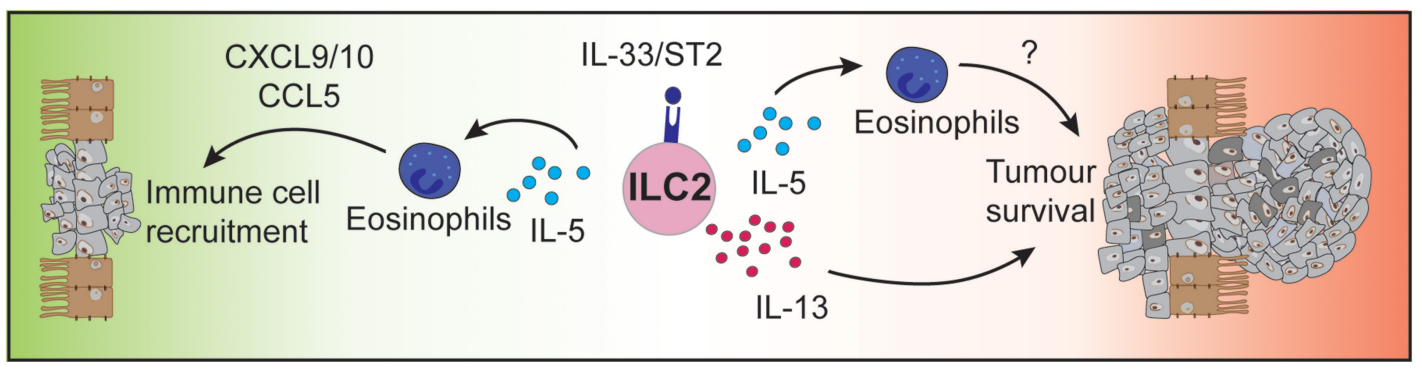

C

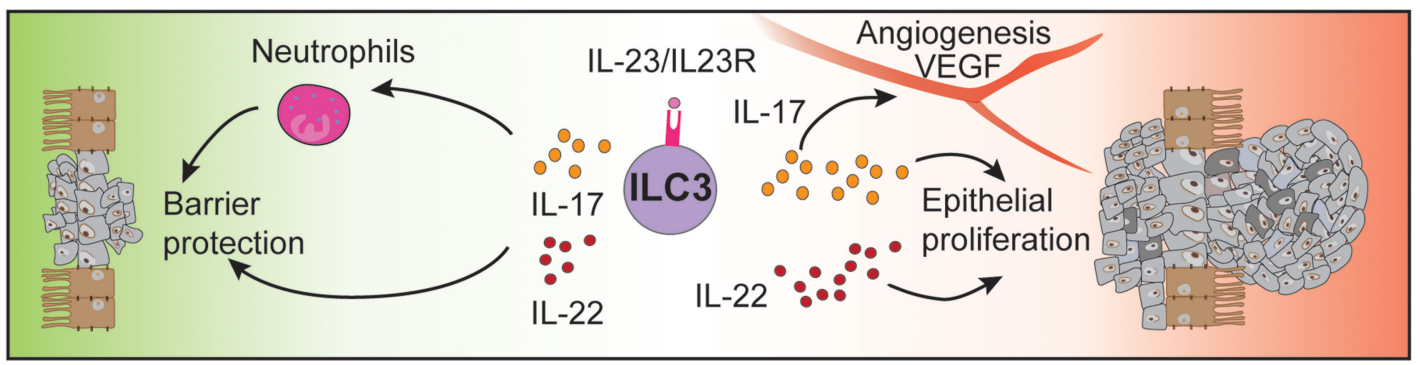

FIGURE 1 | Intestinal ILCs drive both pro- and anti-tumor functions tipping the balance for tumor development. Signaling of NK cells and intraepithelial ILC1 (A), ILC2 (B), and ILC3 (C) through their activatory or inhibitory receptors regulates the function of these immune cells. Through the secretion of cytokines and cytotoxic molecules, ILCs can modulate the tumor microenvironment to either control or promote CRC development and progression.

compared with healthy individuals (74). In CRC tumors, ILC2s express higher levels of ICOS and CD69 compared with ILC2 found in normal colon tissue $(59,60)$. These phenotypically distinct ILC2s could be a potential source of IL-4, IL-5, and IL-13 as both IL-4 and IL-13 are found at elevated levels in the serum of CRC bearing mice (75).

IL-13 can act directly on tumor epithelial cells in both an autocrine or paracrine manner to promote their survival and tumorigenesis (Figure 1B). In CRC, high expression of the IL-13R $\alpha 2$ receptor is associated with more advanced disease stages, lymph node involvement, the presence of metastases and reduced survival (76). In contrast, Saigusa et al. found that low preoperative serum IL-13 was a predictive marker for poorer prognosis of colorectal cancer patients (77). These discrepancies indicate that IL-13 expression and its predictive value may be context dependent. The role of IL-5 has not been explicitly studied in the context of CRC. Nevertheless, it is important for eosinophil recruitment, expansion and activation $(78,79)$. In turn, these cells secrete chemo-attractants such as CXCL9,
CXCL10, and CCL5 which promote the recruitment of CD8 ${ }^{+}$ $\mathrm{T}$ cells to the tumor site (80) (Table 3 and Figure 1B). The presence of peritumoral eosinophils is an independent prognostic factor associated with favorable progression free survival (81). In contrast, patients suffering from ulcerative colitis, have a higher risk of CRC development and were found to have elevated IL-5 transcript levels (82). Neutralizing IL-5 in mice reduced eosinophil numbers and diminished the inflammation associated with DSS-induced colitis (83).

The role of ILC2s, their activation pathways and subsequent downstream signaling in CRC are highly contentious. This is because the same biomarkers or effector molecules (e.g., IL-5 and IL-13) have been found to exhibit opposing roles in CRC outcome, and thus, differentially impact patient prognosis. A similar effect is seen for the cytokine IL-33, a molecule released by damaged epithelial cells and regulator of ILC2 activation. Several studies have found both the cytokine IL-33 and its receptor ST2, to be elevated in mouse and human CRC tissues (84-86), suggesting a potential role of this IL-33/ST2 pathway 
TABLE 3 | Role of ILC in promoting or inhibiting CRC tumorigenesis.

\begin{tabular}{|c|c|c|c|}
\hline \multirow{2}{*}{$\begin{array}{l}\text { Immune } \\
\text { cell type }\end{array}$} & \multicolumn{2}{|c|}{ Prognosis } & \multirow[t]{2}{*}{ References } \\
\hline & Anti-tumor & Pro-tumor & \\
\hline NK cells & $\begin{array}{l}\text { - High cytotoxicity } \\
\text { - Recognition of } \\
\text { cancer initiating cells }\end{array}$ & $\begin{array}{l}\text { - Low number of } \\
\text { infiltrating NK cells } \\
\text { - Reduced level of } \\
\text { activating receptors } \\
\text { (e.g., NKp44, } \\
\text { NKp30) } \\
\text { - Increased expression } \\
\text { of inhibitory } \\
\text { receptors (e.g., } \\
\text { TIGIT) } \\
\text { - Low cytotoxicity }\end{array}$ & $(61,64,65,67)$ \\
\hline ILC1 & $\begin{array}{l}\text { - Produce IFN- } \gamma \text { and } \\
\text { cytotoxic molecules } \\
\text { associated with } \\
\text { anti-tumor immunity* }\end{array}$ & $\begin{array}{l}\text { - Accumulate in } \\
\text { inflamed tissue } \\
\text { - IFN- } \gamma \\
\text { promotes inflammation* }\end{array}$ & $(58,62)$ \\
\hline ILC2 & $\begin{array}{l}\text { - High pre-operative } \\
\text { serum IL-13 } \\
\text { - IL-5 } \\
\text { recruits eosinophils }\end{array}$ & $\begin{array}{l}\text { - Local IL-13 promote } \\
\text { tumor epithelial } \\
\text { survival and } \\
\text { proliferation. } \\
\text { - Elevated IL-5 in } \\
\text { ulcerative colitis, } \\
\text { anti-IL-5 reduced } \\
\text { eosinophils } \\
\text { and colitis* }\end{array}$ & $(76,77,81-83)$ \\
\hline ILC3 & $\begin{array}{l}\text { - IL-17 recruits } \\
\text { neutrophils to protect } \\
\text { tissue barrier } \\
\text { - IL-22 promotes } \\
\text { wound healing }{ }^{\star} \text { and } \\
\text { protects intestinal } \\
\text { epithelial cells from } \\
\text { genotoxic } \\
\text { stress-induced } \\
\text { DNA damage }\end{array}$ & $\begin{array}{l}\text { - Overproduction of } \\
\text { IL-17 promote } \\
\text { inflammation and } \\
\text { angiogenesis, and } \\
\text { disrupt the intestinal } \\
\text { epithelial barrier } \\
\text { - Overproduction of } \\
\text { IL-22 dysregulates } \\
\text { epithelial proliferation }\end{array}$ & $\begin{array}{l}(96,102,103, \\
106,108,109, \\
112,113)\end{array}$ \\
\hline
\end{tabular}

*Indirect evidence of involvement in CRC development.

in tumor development and progression. Mechanistically, IL-33 was found in adenomatous polyposis coli $(A P C)^{\mathrm{min} /+}$ mice to promote intestinal polyp formation by activating stromal cells and modulating angiogenesis $(85,87)$, and by promoting cell growth and proliferation of primary CRC cells (88). Serum soluble ST2 levels were inversely correlated with the tumor stage despite being elevated in CRC patients. Indeed, soluble ST2 was shown to act as a decoy receptor suppressing IL33-driven angiogenesis (89) and inhibiting CRC growth, while loss of ST2 expression conferred protection in AOM/DSSinduced CRC (90). Conversely, reduced levels of serum IL-33 is observed in CRC patients compared with healthy individuals and decreased expression of ST2L, the transmembrane isoform of the ST2 receptor, in CRC tumors is associated with higher tumor grade and worse prognosis (91). These conflicting results indicate that the IL-33/ST2 axis may playing a dual role in CRC pathogenesis and is capable of both promoting or protecting against CRC tumor development and progression depending on the environmental context. IL-33 has multiple downstream targets as ST2 is not only expressed on ILC2 but is also found on other intestinal cell types such as epithelial cells or regulatory $\mathrm{CD}^{+}{ }^{+} \mathrm{T}$ cells (86). Therefore, the role of the IL-33/ST2/ILC2 pathway in CRC warrants further investigation using conditional mouse models, which would allow cell-specific responses to be disected.

\section{Type 3 Innate Lymphoid Cells}

Inflammation is a key driver of cancer progression and the link between IBD and the development of CRC is well-established (92). This inflammation can be exacerbated by the loss of barrier protection occurring early during CRC development (93), allowing for the infiltration of microbes and their associated products into the tumor microenvironment. This activates dendritic cells and macrophages to produce IL-23 (94), a key cytokine regulating ILC3 function and plasticity $(53,95)$. Additional stimuli such as IL-12, IL-18, TGF- $\beta$, or Notch ligand can profoundly influence ILC3 plasticity (50-52). In the presence of IL-12 or TGF- $\beta$, IL-22-expressing ILC3 can acquire ILC1 features and transdifferentiate into IFN- $\gamma$ producing cells (52). At the molecular level, the transcription factors T-BET, AIOLOS, and Signal Transducer and Activator of Transcription (STAT) 4 induce an ILC1 transcriptional program, repressing in parallel the ILC3 lineage genes $(52,53)$. Transitional ILC3/ILC1 cells were found in human intestinal epithelium (52) and accumulate in inflamed lesions of patients suffering from Crohn's disease (51) suggesting that such plasticity may also occur in inflamed CRC lesions.

IL-23 has been found to be overexpressed in both mouse and human CRC tumors $(93,96,97)$ and IL-23 deficiency has been shown to protect against tumor development in a number of mouse models of cancer (97). Conversely, chronic IL-23 injection induces ILC3-dependent duodenal adenomas development in mice (98). Furthermore, local IL-23 expression drives ILC3 accumulation and activation within the colonic lamina propria (99, 100). These intestinal ILC3 express higher levels of the activating receptors $\operatorname{ICOS}$ and $\operatorname{CD} 69(59,60)$, regulators of tumor responses CD244 and CD39 (59), and exhibit enhanced production of the downstream signaling cytokines IL-17 and IL22 that contribute to the pathogenesis of CRC (96) (Table 3 and Figure 1C).

Several studies have reported high IL-17 expression in both mouse and human CRC compared with normal adjacent tissues (96, 101-103). ILC3s produce high levels of IL-17 but other immune and non-immune intestinal cell types also express this cytokine. These include Th17 cells, $\gamma \delta \mathrm{T}$ cells, and Paneth cells (104). Importantly, IL-17 transcripts are increased during progression of tumors from the adenoma to carcinoma stages in CRC patients (105). Furthermore, IL-17 can alleviate cell cycle inhibition, thereby promoting epithelial proliferation and intestinal inflammation (106) and increase angiogenesis by inducing VEGF expression (103). Administration of anti-IL-17 antibodies have been shown to ameliorate inflammation severity (96) while genetic ablation of IL-17 was able to reduce tumor burden $(93,100,106,107)$. Although, these studies show that IL17 is a pro-inflammatory cytokine involved in CRC pathogenesis, IL-17 may also play a protective role. Lin and colleagues (102) reported better patient overall survival associated with high 
IL-17 levels (102) and neutralizing IL-17 exacerbated Crohn's disease and DSS-mediated colitis by increasing gut permeability (108, 109) (Table 1).

In a similar pattern to IL-17, the ILC3-driven IL-22 pathway plays both protective and pathogenic roles during colitis and tumorigenesis (Table 3). Under normal conditions, IL-22 is required for homeostatic epithelial cell proliferation through STAT3 activation $(110,111)$. Furthermore, IL-22 production by ILC3 and $\gamma \delta \mathrm{T}$ cells protects the intestine from genotoxic stress-induced DNA damage through effective initiation of the DNA damage response program (112). Loss of IL-22 or IL22 receptor on epithelial cells results in delayed tissue repair, exacerbated inflammation (113) and tumor development when intestinal cells are exposed to carcinogens (112). Conversely, sustained IL-22-dependent epithelial proliferation leads to tumor progression (Figure 1C) and neutralizing IL-22 reduced CRC development (96). In addition to this, loss of IL-22 binding protein, a soluble decoy receptor neutralizing IL-22driven cell activation, has been shown to increase epithelial cell proliferation and was associated with a higher tumor burden (114).

These studies unanimously suggest that IL-23 signaling in ILC3 is central in driving CRC development. Indeed, the absence of ILC3 despite chronic IL-23 injections protects mice from tumor development (98). However, the downstream cytokine IL-17 and IL-22 signaling pathways seem to play a dual role in CRC. These findings suggest that initial activation of the IL-23/ILC3 pathway is sufficient to trigger tumor development but additional mechanisms influence CRC progression and outcomes. Collectively, further investigations are warranted to shed light on the role of these cytokines in CRC pathogenesis.

\section{CONCLUDING REMARKS}

Despite increasing evidence for the crucial role of the immune system in dictating patient's prognosis, the evaluation of the tumor immune cell infiltration in primary CRC is not yet fully integrated into assessments in routine clinical practice (115).

\section{REFERENCES}

1. International Agency for Research on Cancer. Globocan 2018: Cancer Fact Sheets - Colorectal Cancer. (2018). Available online at: http://gco.iarc.fr/ today/data/factsheets/cancers/10_8_9-Colorectum-fact-sheet.pdf

2. Schreuders EH, Ruco A, Rabeneck L, Schoen RE, Sung JJ, Young GP, et al. Colorectal cancer screening: a global overview of existing programmes. Gut. (2015) 64:1637-49. doi: 10.1136/gutjnl-2014309086

3. Kuipers EJ, Grady WM, Lieberman D, Seufferlein T, Sung JJ, Boelens PG, et al. Colorectal cancer. Nat Rev Dis Primers. (2015) 1:15065. doi: 10.1038/nrdp.2015.65

4. Brenner H, Kloor M, Pox CP. Colorectal cancer. Lancet. (2014) 383:1490502. doi: 10.1016/S0140-6736(13)61649-9

5. Keum N, Giovannucci E. Global burden of colorectal cancer: emerging trends, risk factors and prevention strategies. Nat Rev Gastroenterol Hepatol. (2019) 16:713-32. doi: 10.1038/s41575-019-0189-8

6. De Palma FDE, D'Argenio V, Pol J, Kroemer G, Maiuri MC, Salvatore F. The molecular hallmarks of the serrated pathway in colorectal
It is, however, clear that adaptive immune cells, particularly $\mathrm{CD}^{+}$memory $\mathrm{T}$ cells, play an important role to limit tumor recurrence and prolong patient's survival (30). How adaptive immune cells are influenced by resident innate immune cell populations, the first line of immune defense, is still poorly understood (116). Direct and indirect evidence tend to suggest that ILCs could play a dual role in colorectal cancer. However, most of the aforementioned findings resulted from studying knockout mice or mice lacking adaptive immune cells. Thus, further studies are warranted to ascertain the role of ILCs in immunocompetent animals using genetically-modified conditionally-deficient mouse models. Collectively, given their function and strategic location, harnessing ILC responses would open up new possibilities through the development of combination therapies to further constrain CRC progression.

\section{AUTHOR CONTRIBUTIONS}

$\mathrm{QH}$ and NJ wrote the initial draft. WC designed the figure. All authors provided critical insight, edited, and approved the final version.

\section{FUNDING}

This work was supported by grants and fellowships from the National Health and Medical Research Council (NHMRC) of Australia (APP1165443, 1122277, and 1054925 GB and CS), fellowships from the NHMRC (APP1135898 GB, APP1123000 CS), Victorian Cancer Agency (LM), Cure Cancer Australia and Cancer Australia through the Cancer Australia Priority-driven Cancer Research Scheme (APP1163990 NJ), The Rebecca L. Cooper Foundation Medical Research Foundation (GB), and an Australian Government Research Training Program Scholarship (QH). This work was made possible through Victorian State Government Operational Infrastructure Support and Australian Government NHMRC Independent Research Institute Infrastructure Support scheme. cancer. Cancers (Basel). (2019) 11:E1017. doi: 10.3390/cancers110 71017

7. Nguyen HT, Duong HQ. The molecular characteristics of colorectal cancer: implications for diagnosis and therapy. Oncol Lett. (2018) 16:918. doi: 10.3892/ol.2018.8679

8. Cancer Genome Atlas N. Comprehensive molecular characterization of human colon and rectal cancer. Nature. (2012) 487:3307. doi: $10.1038 /$ nature 11252

9. Kim SE, Paik HY, Yoon H, Lee JE, Kim N, Sung MK. Sex- and genderspecific disparities in colorectal cancer risk. World J Gastroenterol. (2015) 21:5167-75. doi: 10.3748/wjg.v21.i17.5167

10. Jess T, Rungoe C, Peyrin-Biroulet L. Risk of colorectal cancer in patients with ulcerative colitis: a meta-analysis of population-based cohort studies. Clin Gastroenterol Hepatol. (2012) 10:639-45. doi: 10.1016/j.cgh. 2012.01.010

11. Herrinton LJ, Liu L, Levin TR, Allison JE, Lewis JD, Velayos F. Incidence and mortality of colorectal adenocarcinoma in persons with inflammatory bowel disease from 1998 to 2010. Gastroenterology. (2012) 143:3829. doi: 10.1053 /j.gastro.2012.04.054 
12. Clarke WT, Feuerstein JD. Colorectal cancer surveillance in inflammatory bowel disease: practice guidelines and recent developments. World J Gastroenterol. (2019) 25:4148-57. doi: 10.3748/wjg.v25. i30.4148

13. Grothey A, Sargent D, Goldberg RM, Schmoll HJ. Survival of patients with advanced colorectal cancer improves with the availability of fluorouracilleucovorin, irinotecan, and oxaliplatin in the course of treatment. J Clin Oncol. (2004) 22:1209-14. doi: 10.1200/JCO.2004.11.037

14. Cassidy J, Clarke S, Diaz-Rubio E, Scheithauer W, Figer A, Wong $\mathrm{R}$, et al. XELOX vs FOLFOX-4 as first-line therapy for metastatic colorectal cancer: NO16966 updated results. Br J Cancer. (2011) 105:5864. doi: 10.1038/bjc.2011.201

15. Piawah S, Venook AP. Targeted therapy for colorectal cancer metastases: a review of current methods of molecularly targeted therapy and the use of tumor biomarkers in the treatment of metastatic colorectal cancer. Cancer. (2019) 125:4139-47. doi: 10.1002/cncr.32163

16. Hurwitz H, Fehrenbacher L, Novotny W, Cartwright T, Hainsworth J, Heim W, et al. Bevacizumab plus irinotecan, fluorouracil, and leucovorin for metastatic colorectal cancer. N Engl J Med. (2004) 350:233542. doi: 10.1056/NEJMoa032691

17. Hurwitz HI, Tebbutt NC, Kabbinavar F, Giantonio BJ, Guan ZZ, Mitchell L, et al. Efficacy and safety of bevacizumab in metastatic colorectal cancer: pooled analysis from seven randomized controlled trials. Oncologist. (2013) 18:1004-12. doi: 10.1634/theoncologist.2013-0107

18. Ribas A, Wolchok JD. Cancer immunotherapy using checkpoint blockade. Science. (2018) 359:1350-5. doi: 10.1126/science.aar4060

19. Hirsch L, Zitvogel L, Eggermont A, Marabelle A. PD-Loma: a cancer entity with a shared sensitivity to the PD-1/PD-L1 pathway blockade. Br J Cancer. (2019) 120:3-5. doi: 10.1038/s41416-018-0294-4

20. Le DT, Uram JN, Wang H, Bartlett BR, Kemberling H, Eyring AD, et al. PD1 blockade in tumors with mismatch-repair deficiency. N Engl J Med. (2015) 372:2509-20. doi: 10.1056/NEJMoa1500596

21. Zaravinos A, Roufas C, Nagara M, de Lucas Moreno B, Oblovatskaya M, Efstathiades C, et al. Cytolytic activity correlates with the mutational burden and deregulated expression of immune checkpoints in colorectal cancer. $J$ Exp Clin Cancer Res. (2019) 38:364. doi: 10.1186/s13046-019-1372-z

22. Le DT, Durham JN, Smith KN, Wang H, Bartlett BR, Aulakh LK, et al. Mismatch repair deficiency predicts response of solid tumors to PD-1 blockade. Science. (2017) 357:409-13. doi: 10.1126/science.aan6733

23. Grasso CS, Giannakis M, Wells DK, Hamada T, Mu XJ, Quist M, et al. Genetic mechanisms of immune evasion in colorectal cancer. Cancer Discov. (2018) 8:730-49. doi: 10.1158/2159-8290.CD-17-1327

24. Overman MJ, Lonardi S, Wong KYM, Lenz HJ, Gelsomino F, Aglietta M, et al. Durable clinical benefit with nivolumab plus ipilimumab in DNA mismatch repair-deficient/microsatellite instability-high metastatic colorectal cancer. $J$ Clin Oncol. (2018) 36:773-9. doi: 10.1200/JCO.2017.76.9901

25. Wilt C, Le DT. Integrating immunotherapy into colorectal cancer care. Oncology. (2018) 32:494-8.

26. Fleming M, Ravula S, Tatishchev SF, Wang HL. Colorectal carcinoma: pathologic aspects. J Gastrointest Oncol. (2012) 3:153-73. doi: 10.3978/j.issn.2078-6891.2012.030

27. Zitvogel L, Tesniere A, Kroemer G. Cancer despite immunosurveillance: immunoselection and immunosubversion. Nat Rev Immunol. (2006) 6:71527. doi: $10.1038 /$ nri1936

28. Fridman WH, Zitvogel L, Sautes-Fridman C, Kroemer G. The immune contexture in cancer prognosis and treatment. Nat Rev Clin Oncol. (2017) 14:717-34. doi: 10.1038/nrclinonc.2017.101

29. Mlecnik B, Van den Eynde M, Bindea G, Church SE, Vasaturo A, Fredriksen $\mathrm{T}$, et al. Comprehensive intrametastatic immune quantification and major impact of immunoscore on survival. J Natl Cancer Inst. (2018) 110:97108. doi: 10.1093/jnci/djx123

30. Galon J, Costes A, Sanchez-Cabo F, Kirilovsky A, Mlecnik B, LagorcePages C, et al. Type, density, and location of immune cells within human colorectal tumors predict clinical outcome. Science. (2006) 313:19604. doi: 10.1126/science.1129139

31. Pages F, Berger A, Camus M, Sanchez-Cabo F, Costes A, Molidor R, et al. Effector memory T cells, early metastasis, and survival in colorectal cancer. N Engl J Med. (2005) 353:2654-66. doi: 10.1056/NEJMoa051424
32. Bindea G, Mlecnik B, Tosolini M, Kirilovsky A, Waldner M, Obenauf AC, et al. Spatiotemporal dynamics of intratumoral immune cells reveal the immune landscape in human cancer. Immunity. (2013) 39:78295. doi: 10.1016/j.immuni.2013.10.003

33. Angell HK, Bruni D, Barrett JC, Herbst R, Galon J. The immunoscore: colon cancer and beyond. Clin Cancer Res. (2019). doi: 10.1158/1078-0432.CCR-18-1851. [Epub ahead of print].

34. Mlecnik B, Bindea G, Kirilovsky A, Angell HK, Obenauf AC, Tosolini $\mathrm{M}$, et al. The tumor microenvironment and Immunoscore are critical determinants of dissemination to distant metastasis. Sci Transl Med. (2016) 8:327ra26. doi: 10.1126/scitranslmed.aad6352

35. Mlecnik B, Tosolini M, Kirilovsky A, Berger A, Bindea G, Meatchi T, et al. Histopathologic-based prognostic factors of colorectal cancers are associated with the state of the local immune reaction. J Clin Oncol. (2011) 29:6108. doi: 10.1200/JCO.2010.30.5425

36. Vivier E, Artis D, Colonna M, Diefenbach A, Di Santo JP, Eberl G, et al. Innate lymphoid cells: 10 years on. Cell. (2018) 174:105466. doi: 10.1016/j.cell.2018.07.017

37. Almeida FF, Jacquelot N, Belz GT. Deconstructing deployment of the innate immune lymphocyte army for barrier homeostasis and protection. Immunol Rev. (2018) 286:6-22. doi: 10.1111/imr.12709

38. Seillet C, Jacquelot N. Sensing of physiological regulators by innate lymphoid cells. Cell Mol Immunol. (2019) 16:442-51. doi: 10.1038/s41423-019-0217-1

39. Jacquelot N, Luong K, Seillet C. Physiological regulation of innate lymphoid cells. Front Immunol. (2019) 10:405. doi: 10.3389/fimmu.2019.00405

40. Taylor S, Huang Y, Mallett G, Stathopoulou C, Felizardo TC, Sun MA, et al. PD-1 regulates KLRG1(+) group 2 innate lymphoid cells. J Exp Med. (2017) 214:1663-78. doi: 10.1084/jem.20161653

41. Bi J, Tian Z. NK cell dysfunction and checkpoint immunotherapy. Front Immunol. (2019) 10:1999. doi: 10.3389/fimmu.2019.01999

42. Weizman OE, Adams NM, Schuster IS, Krishna C, Pritykin Y, Lau C, et al. ILC1 Confer early host protection at initial sites of viral infection. Cell. (2017) 171:795-808.e12. doi: 10.1016/j.cell.2017.09.052

43. Klose CSN, Flach M, Möhle L, Rogell L, Hoyler T, Ebert K, et al. Differentiation of type 1 ILCs from a common progenitor to all helper-like innate lymphoid cell lineages. Cell. (2014) 157:340-56. doi: 10.1016/j.cell.2014.03.030

44. Abt MC, Lewis BB, Caballero S, Xiong H, Carter RA, Susac B, et al. Innate immune defenses mediated by two ILC subsets are critical for protection against acute clostridium difficile infection. Cell Host Microbe. (2015) 18:2737. doi: 10.1016/j.chom.2015.06.011

45. Nicholson SE, Keating N, Belz GT. Natural killer cells and anti-tumor immunity. Mol Immunol. (2019) 110:407. doi: 10.1016/j.molimm.2017.12.002

46. Cuturi MC, Anegon I, Sherman F, Loudon R, Clark SC, Perussia B, et al. Production of hematopoietic colony-stimulating factors by human natural killer cells. J Exp Med. (1989) 169:569-83. doi: 10.1084/jem.169.2.569

47. Huang Y, Guo L, Qiu J, Chen X, Hu-Li J, Siebenlist U, et al. IL-25-responsive, lineage-negative KLRG1(hi) cells are multipotential 'inflammatory' type 2 innate lymphoid cells. Nat Immunol. (2015) 16:161-9. doi: 10.1038/ni.3078

48. Rankin LC, Girard-Madoux MJ, Seillet C, Mielke LA, Kerdiles Y, Fenis A, et al. Complementarity and redundancy of IL-22-producing innate lymphoid cells. Nat Immunol. (2016) 17:179-86. doi: 10.1038/ni.3332

49. Eberl G, Marmon S, Sunshine MJ, Rennert PD, Choi Y, Littman DR. An essential function for the nuclear receptor RORgamma(t) in the generation of fetal lymphoid tissue inducer cells. Nat Immunol. (2004) 5:64-73. doi: 10.1038/ni1022

50. Viant C, Rankin LC, Girard-Madoux MJ, Seillet C, Shi W, Smyth MJ, et al. Transforming growth factor-beta and Notch ligands act as opposing environmental cues in regulating the plasticity of type 3 innate lymphoid cells. Sci Signal. (2016) 9:ra46. doi: 10.1126/scisignal.aaf2176

51. Bernink JH, Peters CP, Munneke M, te Velde AA, Meijer SL, Weijer K, et al. Human type 1 innate lymphoid cells accumulate in inflamed mucosal tissues. Nat Immunol. (2013) 14:221-9. doi: 10.1038/ni.2534

52. Cella M, Gamini R, Secca C, Collins PL, Zhao S, Peng V, et al. Subsets of ILC3-ILC1-like cells generate a diversity spectrum of innate lymphoid cells in human mucosal tissues. Nat Immunol. (2019) 20:98091. doi: 10.1038/s41590-019-0425-y 
53. Mikami Y, Scarno G, Zitti B, Shih HY, Kanno Y, Santoni A, et al. NCR(+) ILC3 maintain larger STAT4 reservoir via T-BET to regulate type 1 features upon IL-23 stimulation in mice. Eur J Immunol. (2018) 48:117480. doi: 10.1002/eji.201847480

54. Gao Y, Souza-Fonseca-Guimaraes F, Bald T, Ng SS, Young A, Ngiow SF, et al. Tumor immunoevasion by the conversion of effector NK cells into type 1 innate lymphoid cells. Nat Immunol. (2017) 18:1004-15. doi: 10.1038/ni.3800

55. Cortez VS, Ulland TK, Cervantes-Barragan L, Bando JK, Robinette ML, Wang Q, et al. SMAD4 impedes the conversion of NK cells into ILC1-like cells by curtailing non-canonical TGF-beta signaling. Nat Immunol. (2017) 18:995-1003. doi: 10.1038/ni.3809

56. Boulenouar S, Michelet X, Duquette D, Alvarez D, Hogan AE, Dold $\mathrm{C}$, et al. Adipose type one innate lymphoid cells regulate macrophage homeostasis through targeted cytotoxicity. Immunity. (2017) 46:27386. doi: 10.1016/j.immuni.2017.01.008

57. Laffont S, Blanquart E, Savignac M, Cenac C, Laverny G, Metzger D, et al. Androgen signaling negatively controls group 2 innate lymphoid cells. J Exp Med. (2017) 214:1581-92. doi: 10.1084/jem.20161807

58. Mattner J, Wirtz S. Friend or foe? The ambiguous role of innate lymphoid cells in cancer development. Trends Immunol. (2017) 38:2938. doi: 10.1016/j.it.2016.10.004

59. Simoni Y, Fehlings M, Kloverpris HN, McGovern N, Koo SL, Loh CY, et al. Human innate lymphoid cell subsets possess tissue-type based heterogeneity in phenotype and frequency. Immunity. (2017) 46:14861. doi: 10.1016/j.immuni.2016.11.005

60. de Vries NL, van Unen V, Ijsselsteijn ME, Abdelaal T, van der Breggen R, Farina Sarasqueta A, et al. High-dimensional cytometric analysis of colorectal cancer reveals novel mediators of antitumour immunity. Gut. (2019). doi: 10.1136/gutjnl-2019-318672. [Epub ahead of print].

61. Halama N, Braun M, Kahlert C, Spille A, Quack C, Rahbari N, et al. Natural killer cells are scarce in colorectal carcinoma tissue despite high levels of chemokines and cytokines. Clin Cancer Res. (2011) 17:67889. doi: 10.1158/1078-0432.CCR-10-2173

62. Fuchs A, Vermi W, Lee JS, Lonardi S, Gilfillan S, Newberry RD, et al. Intraepithelial type 1 innate lymphoid cells are a unique subset of IL12 - and IL-15-responsive IFN- $\gamma$-producing cells. Immunity. (2013) 38:76981. doi: 10.1016/j.immuni.2013.02.010

63. Okazawa A, Kanai T, Nakamaru K, Sato T, Inoue N, Ogata H, et al. Human intestinal epithelial cell-derived interleukin (IL)-18, along with IL-2, IL-7 and IL-15, is a potent synergistic factor for the proliferation of intraepithelial lymphocytes. Clin Exp Immunol. (2004) 136:26976. doi: 10.1111/j.1365-2249.2004.02431.x

64. Tallerico R, Todaro M, Di Franco S, Maccalli C, Garofalo C, Sottile R, et al. Human NK cells selective targeting of colon cancer-initiating cells: a role for natural cytotoxicity receptors and MHC class I molecules. J Immunol. (2013) 190:2381-90. doi: 10.4049/jimmunol.1201542

65. Krijgsman D, de Vries NL, Skovbo A, Andersen MN, Swets M, Bastiaannet E, et al. Characterization of circulating T-, NK-, and NKT cell subsets in patients with colorectal cancer: the peripheral blood immune cell profile. Cancer Immunol Immunother. (2019) 68:1011-24. doi: 10.1007/s00262-019-02343-7

66. Barani S, Hosseini SV, Ghaderi A. Activating and inhibitory killer cell immunoglobulin like receptors (KIR) genes are involved in an increased susceptibility to colorectal adenocarcinoma and protection against invasion and metastasis. Immunobiology. (2019) 224:681-6. doi: 10.1016/j.imbio.2019.06.002

67. Zhang Q, Bi J, Zheng X, Chen Y, Wang H, Wu W, et al. Blockade of the checkpoint receptor TIGIT prevents NK cell exhaustion and elicits potent anti-tumor immunity. Nat Immunol. (2018) 19:723-32. doi: 10.1038/s41590-018-0132-0

68. Cantoni C, Huergo-Zapico L, Parodi M, Pedrazzi M, Mingari MC, Moretta A, et al. NK cells, tumor cell transition, and tumor progression in solid malignancies: new hints for NK-based immunotherapy? J Immunol Res. (2016) 2016:4684268. doi: 10.1155/2016/ 4684268

69. Souza-Fonseca-Guimaraes F, Cursons J, Huntington ND. The emergence of natural killer cells as a major target in cancer immunotherapy. Trends Immunol. (2019) 40:142-58. doi: 10.1016/j.it.2018. 12.003
70. Hodgins JJ, Khan ST, Park MM, Auer RC, Ardolino M. Killers 2.0: NK cell therapies at the forefront of cancer control. J Clin Invest. (2019) 129:3499510. doi: 10.1172/JCI129338

71. Demaria O, Cornen S, Daeron M, Morel Y, Medzhitov R, Vivier E. Harnessing innate immunity in cancer therapy. Nature. (2019) 574:4556. doi: 10.1038/s41586-019-1593-5

72. Ikutani M, Yanagibashi T, Ogasawara M, Tsuneyama K, Yamamoto S, Hattori $\mathrm{Y}$, et al. Identification of innate IL-5-producing cells and their role in lung eosinophil regulation and antitumor immunity. J Immunol. (2012) 188:70313. doi: $10.4049 /$ jimmunol.1101270

73. Bie Q, Zhang $\mathrm{P}$, Su Z, Zheng D, Ying X, Wu Y, et al. Polarization of ILC2s in peripheral blood might contribute to immunosuppressive microenvironment in patients with gastric cancer. J Immunol Res. (2014) 2014:923135. doi: 10.1155/2014/923135

74. Forkel M, van Tol S, Hoog C, Michaelsson J, Almer S, Mjosberg J. Distinct alterations in the composition of mucosal innate lymphoid cells in newly diagnosed and established Crohn's disease and ulcerative colitis. J Crohns Colitis. (2019) 13:67-78. doi: 10.1093/ecco-jcc/jjy119

75. Zhou Y, Ji Y, Wang $H$, Zhang H, Zhou H. IL-33 Promotes the development of colorectal cancer through inducing tumor-infiltrating ST2L(+) regulatory $\mathrm{T}$ cells in mice. Technol Cancer Res Treat. (2018) 17:1533033818780091. doi: 10.1177/1533033818780091

76. Barderas R, Bartolome RA, Fernandez-Acenero MJ, Torres S, Casal JI. High expression of IL-13 receptor alpha2 in colorectal cancer is associated with invasion, liver metastasis, and poor prognosis. Cancer Res. (2012) 72:278090. doi: 10.1158/0008-5472.CAN-11-4090

77. Saigusa S, Tanaka K, Inoue Y, Toiyama Y, Okugawa Y, Iwata $\mathrm{T}$, et al. Low serum interleukin-13 levels correlate with poorer prognoses for colorectal cancer patients. Int Surg. (2014) 99:223-9. doi: 10.9738/INTSURG-D-13-00259.1

78. Yamaguchi Y, Hayashi Y, Sugama Y, Miura Y, Kasahara T, Kitamura S, et al. Highly purified murine interleukin 5 (IL-5) stimulates eosinophil function and prolongs in vitro survival. IL-5 as an eosinophil chemotactic factor. $J$ Exp Med. (1988) 167:1737-42. doi: 10.1084/jem.167.5.1737

79. Yamaguchi Y, Suda T, Suda J, Eguchi M, Miura Y, Harada N, et al. Purified interleukin 5 supports the terminal differentiation and proliferation of murine eosinophilic precursors. J Exp Med. (1988) 167:43-56. doi: 10.1084/jem.167.1.43

80. Carretero R, Sektioglu IM, Garbi N, Salgado OC, Beckhove P, Hammerling GJ. Eosinophils orchestrate cancer rejection by normalizing tumor vessels and enhancing infiltration of CD8(+) T cells. Nat Immunol. (2015) 16:60917. doi: 10.1038/ni.3159

81. Harbaum L, Pollheimer MJ, Kornprat P, Lindtner RA, Bokemeyer C, Langner C. Peritumoral eosinophils predict recurrence in colorectal cancer. Mod Pathol. (2015) 28:403-13. doi: 10.1038/modpathol.2014.104

82. Nemeth ZH, Bogdanovski DA, Barratt-Stopper P, Paglinco SR, Antonioli L, Rolandelli RH. Crohn's disease and ulcerative colitis show unique cytokine profiles. Cureus. (2017) 9:e1177. doi: 10.7759/cureus.1177

83. Abo H, Flannigan KL, Geem D, Ngo VL, Harusato A, Denning TL. Combined IL-2 Immunocomplex and anti-IL-5 mAb treatment expands Foxp3(+) Treg cells in the absence of eosinophilia and ameliorates experimental colitis. Front Immunol. (2019) 10:459. doi: 10.3389/fimmu.2019.00459

84. Cui G, Qi H, Gundersen MD, Yang H, Christiansen I, Sorbye SW, et al. Dynamics of the IL-33/ST2 network in the progression of human colorectal adenoma to sporadic colorectal cancer. Cancer Immunol Immunother. (2015) 64:181-90. doi: 10.1007/s00262-014-1624-x

85. Maywald RL, Doerner SK, Pastorelli L, De Salvo C, Benton SM, Dawson EP, et al. IL-33 activates tumor stroma to promote intestinal polyposis. Proc Natl Acad Sci USA. (2015) 112:E2487-96. doi: 10.1073/pnas.1422445112

86. Pastille E, Wasmer MH, Adamczyk A, Vu VP, Mager LF, Phuong NNT, et al. The IL-33/ST2 pathway shapes the regulatory $\mathrm{T}$ cell phenotype to promote intestinal cancer. Mucosal Immunol. (2019) 12:9901003. doi: 10.1038/s41385-019-0176-y

87. Zhang Y, Davis C, Shah S, Hughes D, Ryan JC, Altomare D, et al. IL33 promotes growth and liver metastasis of colorectal cancer in mice by remodeling the tumor microenvironment and inducing angiogenesis. $\mathrm{Mol}$ Carcinog. (2017) 56:272-87. doi: 10.1002/mc.22491 
88. Li Y, Shi J, Qi S, Zhang J, Peng D, Chen Z, et al. IL-33 facilitates proliferation of colorectal cancer dependent on COX2/PGE2. J Exp Clin Cancer Res. (2018) 37:196. doi: 10.1186/s13046-018-0839-7

89. Akimoto M, Maruyama R, Takamaru H, Ochiya $T$, Takenaga K. Soluble IL-33 receptor sST2 inhibits colorectal cancer malignant growth by modifying the tumour microenvironment. Nat Commun. (2016) 7:13589. doi: $10.1038 /$ ncomms 13589

90. Mertz KD, Mager LF, Wasmer MH, Thiesler T, Koelzer VH, Ruzzante G, et al. The IL-33/ST2 pathway contributes to intestinal tumorigenesis in humans and mice. Oncoimmunology. (2016) 5:e1062966. doi: 10.1080/2162402X.2015.1062966

91. O’Donnell C, Mahmoud A, Keane J, Murphy C, White D, Carey S, et al. An antitumorigenic role for the IL-33 receptor, ST2L, in colon cancer. $\mathrm{Br}$ J Cancer. (2016) 114:37-43. doi: 10.1038/bjc.2015.433

92. Morson BC. Precancer and cancer in inflammatory bowel disease. Pathology. (1985) 17:173-80. doi: 10.3109/00313028509063753

93. Grivennikov SI, Wang K, Mucida D, Stewart CA, Schnabl B, Jauch D, et al. Adenoma-linked barrier defects and microbial products drive IL-23/IL-17-mediated tumour growth. Nature. (2012) 491:254-8. doi: 10.1038/nature11465

94. Oppmann B, Lesley R, Blom B, Timans JC, Xu Y, Hunte B, et al. Novel p19 protein engages IL-12p40 to form a cytokine, IL-23, with biological activities similar as well as distinct from IL-12. Immunity. (2000) 13:71525. doi: 10.1016/S1074-7613(00)00070-4

95. Zheng Y, Valdez PA, Danilenko DM, Hu Y, Sa SM, Gong Q, et al. Interleukin22 mediates early host defense against attaching and effacing bacterial pathogens. Nat Med. (2008) 14:282-9. doi: 10.1038/nm1720

96. Kirchberger S, Royston DJ, Boulard O, Thornton E, Franchini F, Szabady $\mathrm{RL}$, et al. Innate lymphoid cells sustain colon cancer through production of interleukin-22 in a mouse model. J Exp Med. (2013) 210:91731. doi: $10.1084 /$ jem.20122308

97. Langowski JL, Zhang X, Wu L, Mattson JD, Chen T, Smith K, et al. IL-23 promotes tumour incidence and growth. Nature. (2006) 442:4615. doi: $10.1038 /$ nature 04808

98. Chan IH, Jain R, Tessmer MS, Gorman D, Mangadu R, Sathe $\mathrm{M}$, et al. Interleukin-23 is sufficient to induce rapid de novo gut tumorigenesis, independent of carcinogens, through activation of innate lymphoid cells. Mucosal Immunol. (2014) 7:842-56. doi: 10.1038/mi. 2013.101

99. Chen L, He Z, Slinger E, Bongers G, Lapenda TLS, Pacer ME, et al. IL-23 activates innate lymphoid cells to promote neonatal intestinal pathology. Mucosal Immunol. (2015) 8:390-402. doi: 10.1038/mi. 2014.77

100. Buonocore S, Ahern PP, Uhlig HH, Ivanov, II, Littman DR, Maloy KJ, et al. Innate lymphoid cells drive interleukin-23-dependent innate intestinal pathology. Nature. (2010) 464:1371-5. doi: 10.1038/nature08949

101. Cui G, Yang H, Zhao J, Yuan A, Florholmen J. Elevated proinflammatory cytokine IL-17A in the adjacent tissues along the adenoma-carcinoma sequence. Pathol Oncol Res. (2015) 21:139-46. doi: 10.1007/s12253-014-9799-1

102. Lin $\mathrm{Y}, \mathrm{Xu}$ J, Su H, Zhong W, Yuan Y, Yu Z, et al. Interleukin-17 is a favorable prognostic marker for colorectal cancer. Clin Transl Oncol. (2015) 17:50-6. doi: 10.1007/s12094-014-1197-3

103. Liu J, Duan Y, Cheng X, Chen X, Xie W, Long H, et al. IL-17 is associated with poor prognosis and promotes angiogenesis via stimulating VEGF production of cancer cells in colorectal carcinoma. Biochem Biophys Res Commun. (2011) 407:348-54. doi: 10.1016/j.bbrc.2011.03.021

104. Cua DJ, Tato CM. Innate IL-17-producing cells: the sentinels of the immune system. Nat Rev Immunol. (2010) 10:479-89. doi: 10.1038/nri2800
105. Cui G, Yuan A, Goll R, Florholmen J. IL-17A in the tumor microenvironment of the human colorectal adenomacarcinoma sequence. Scand J Gastroenterol. (2012) 47:130412. doi: 10.3109/00365521.2012.725089

106. Hyun YS, Han DS, Lee AR, Eun CS, Youn J, Kim HY. Role of IL-17A in the development of colitis-associated cancer. Carcinogenesis. (2012) 33:9316. doi: $10.1093 /$ carcin/bgs106

107. Chae WJ, Gibson TF, Zelterman D, Hao L, Henegariu O, Bothwell AL. Ablation of IL-17A abrogates progression of spontaneous intestinal tumorigenesis. Proc Natl Acad Sci USA. (2010) 107:5540-4. doi: 10.1073/pnas.0912675107

108. Maxwell JR, Zhang Y, Brown WA, Smith CL, Byrne FR, Fiorino $M$, et al. Differential roles for interleukin-23 and interleukin-17 in intestinal immunoregulation. Immunity. (2015) 43:739-50. doi: 10.1016/j.immuni.2015.08.019

109. Lee JS, Tato CM, Joyce-Shaikh B, Gulen MF, Cayatte C, Chen Y, et al. Interleukin-23-independent IL-17 production regulates intestinal epithelial permeability. Immunity. (2015) 43:727-38. doi: 10.1016/j.immuni.2015.10.019

110. Neufert C, Pickert G, Zheng Y, Wittkopf N, Warntjen M, Nikolaev A, et al. Activation of epithelial STAT3 regulates intestinal homeostasis. Cell Cycle. (2010) 9:652-5. doi: 10.4161/cc.9.4.10615

111. Pickert G, Neufert C, Leppkes M, Zheng Y, Wittkopf N, Warntjen M, et al. STAT3 links IL-22 signaling in intestinal epithelial cells to mucosal wound healing. J Exp Med. (2009) 206:1465-72. doi: 10.1084/jem.20082683

112. Gronke K, Hernandez PP, Zimmermann J, Klose CSN, Kofoed-Branzk $\mathrm{M}$, Guendel F, et al. Interleukin-22 protects intestinal stem cells against genotoxic stress. Nature. (2019) 566:249-53. doi: 10.1038/s41586-019-0899-7

113. Zenewicz LA, Yancopoulos GD, Valenzuela DM, Murphy AJ, Stevens S, Flavell RA. Innate and adaptive interleukin-22 protects mice from inflammatory bowel disease. Immunity. (2008) 29:947-57. doi: 10.1016/j.immuni.2008.11.003

114. Huber S, Gagliani N, Zenewicz LA, Huber FJ, Bosurgi L, Hu B, et al. IL-22BP is regulated by the inflammasome and modulates tumorigenesis in the intestine. Nature. (2012) 491:259-63. doi: 10.1038/ nature 11535

115. Pages F, Mlecnik B, Marliot F, Bindea G, Ou FS, Bifulco C, et al. International validation of the consensus Immunoscore for the classification of colon cancer: a prognostic and accuracy study. Lancet. (2018) 391:2128-39. doi: 10.1016/S0140-6736(18) 30789-X

116. Sonnenberg GF, Hepworth MR. Functional interactions between innate lymphoid cells and adaptive immunity. Nat Rev Immunol. (2019) 19:599613. doi: 10.1038/s41577-019-0194-8

Conflict of Interest: The authors declare that the research was conducted in the absence of any commercial or financial relationships that could be construed as a potential conflict of interest.

The reviewer DW declared a past co-authorship with one of the authors GB to the handling editor.

Copyright (C) 2020 Huang, Cao, Mielke, Seillet, Belz and Jacquelot. This is an openaccess article distributed under the terms of the Creative Commons Attribution License (CC BY). The use, distribution or reproduction in other forums is permitted, provided the original author(s) and the copyright owner(s) are credited and that the original publication in this journal is cited, in accordance with accepted academic practice. No use, distribution or reproduction is permitted which does not comply with these terms. 